\title{
From Administration to Socialization: the Change of Public Service in China \\ Wan Taiyong \\ (
}

\begin{abstract}
Public service socialized started in 1980s in China after the reform and opening up. For the transition from administration to socialization, the public service system in China will have a different development, much more competitive and market orientation. This article has an overview of the public service situation in China now. Then discuss the benefit for this kind of transition to transfer the government functions, for Fair competition and changing thoughts of government. And ways to promote public service socialization like public management contract, public management commission, government financial assistants etc.
\end{abstract}

Keywords: Public Service, Change, Socialization.

\section{Introduction}

Public service socialized began from the "New Public Management" campaign in 1970 s in western countries like Britain and U.S.A. The socialization of public service has been practice and development in many countries since then. Before 1980s the public service system in China is majority the administration form, which means that the government took all the responsibilities of public services and public goods provision. There is no market competition for the supplements of public services at that time. Afterward, Chinese government started to change the ways of public services supply, especially after the reform and opening up. There are several benefits for the government to change the public service from administration to socialization. It may take a long time for this transition, but it is a good phenomenon for the society.

\section{Definitions and Current Situation}

\subsection{Public Service}

Public service is not only the services that governments/organizations provide to the citizens, but as Elmer Staats (1988) said: “'Public service' is a concept, and an attitude, a sense of duty - yes, even a sense of public morality." Towards Staats's understanding, which is in fact reflect the breadth and depth for what public service is.

\subsection{Public Service Socialization}

Simply, Public Service Socialization is the introduction of market mechanisms into public services. It is equal to change the provision ways ofpublic services and public goods provided by government departments or state-owned enterprises.By socialization, government will use of force in society -- "the third sector" to provide public services and public goods to the public.The public servicesocialization break the monopoly of government in public services and goods, allowing " the third sector" to compete in the supply of public services, so that can combine the advantages of the government's authority and market organic to improve the efficiency and quality of public services.

\subsection{Situation in China}

Just as Wang (2004) mentioned: it has become a kind of not reversible historical tendency that turns that public service socialization and market melt. The public service system in China, nowadays, is facing a transition from administration to socialization. As China's reform and opening up, the government gradually withdrew from direct management of the 
economy and the direct provision of public services.And shift to macro-management-based regulation and supervision of social services. Many social functions of the government before were transferred to a variety of social organizations.The policy and the development of social organizations surely promote the change of public service from administration to socialization. Although, at present, there are several problems in the construction of public service, such as inadequate investment, small investment amount, narrow coverage, irrational structure, unformed mechanism of multiple social participations, and the public service capacity to further improve, etc. (Zhang Yan-li, 2009) The change of public service is necessary for society and government responsibility in China.

\section{The Benefits for Public Service Socialization}

Since the founding of the People Republic of China till the reform and opening up, the planned economy lead the Chinese society. In the public service realm, government takes the majority of responsibilities. This kind of system makes a huge burden for government and leads to the expansion of the governmental agencies as well as financial burden to the whole nation. From 1980s, developed countries like the UK and U.S.A tried to use the socialized public services, which encourage the social strength to provide the public services and public goods and the governments purchase for them. As a new sort of public service system, the socialization of public service makes many benefits for the entirely society and the management of nation.

\subsection{Transfer theGovernment Functions}

The core to transfer the government functions is the implementation of socialized public service. After the implementation of the separation between government and enterprises, enterprises have operational autonomy.It is inevitable that the enterprises in order to maximize profits are likely to use its market dominance and lower the quality of service. The implementation of public service socialization, we need the transformation of government functions. It is government's responsibility to take the necessary regulatory measures to regulate enterprises' market behavior. At the same time make the regulations for the enterprise to enter and exit the market. These ways will help to improve the management efficiency of the government.

\subsection{Fair Competition}

Competition is a fundamental way to improve the economic efficiency of public services. In the past, the government just changes the ownership structure in the field of public service. The function to promote competition by changing the state-ownedenterprises become private ones is not enough in Chinese society.For the reform of public services by the transition from administration to socialization is a continuous process of strengthening the competitive mechanism. Socialization of public services has a huge effectto make a reasonable competition to enhance economic efficiency of public services. This will not only stimulate internal efficiency of enterprises and promote social distribution, but also help to improve the administrative functions of government.

\subsection{Changing Thoughts of Government}

The thoughts of government need further change.There are different degrees of individual economic situations in various fields intake limit, showing the status of the investment structure is unbalanced. Therefore, measures of public services socialization should focus on preventing these 
disadvantages. Through socialization, government should clarify responsibilities of different departments. The governmental officials have to abandon the concept of manage everything, but to help the private sector to establish confidence of the government.Meanwhile, it is necessary to make the private sector aware of their rights and courage them to take the social responsibility and cooperate with government to solve the problems during the public service socialization.

\section{Ways to Promote Public Service Socialization}

There are many way to promote public service socialization and some of them also gained success after the implementation in developed countries. But due to the difference of national conditions they are not all suitable for China especially the socialist market economy system we have. In China, the ways to promote public service socialization can use as following:

\subsection{The Public Management Contract}

Public Management Contract is refer to the deal that the government has with the enterprises, the third sector or other organizations to supply the public services and public goods. This way can be used for the supplement of public goods, such as the construction of infrastructures and public projects. This kind of goods has the character with normative economics of natural monopoly products. And some parts of public services realm like park and library management, the supplement of water, the legal services etc.

\subsection{The Public ManagementCommission}

Public Management Commission refers to a kind of legal acts the administrative executive and the organization (within its terms of reference) entrust the enterprise, community organization or third sector in a particular or certain aspects of the management of public affairs. The usual way for this is the government takes the responsible for providing the goods and services, the third sectorshave deals with governmental to implement.

\subsection{Government Financial Assistance}

The best way to organize an indirect cause of the government is to promote the reform of institutions.Imposing administrative separated from the social programs.Giving the social matters for the independent non-profit organizations, the government can encourage and guide their development by way of direct or indirect financial assistance and related regulatory instruments. Mainly subsidization can give to departments like engaged in cultural, noncompulsory education, health, religious, charitable, museums and other institutions. The subsidization can in the form of the subsidies, preferential loans, tax breaks, direct investment etc.

There are also some ways like governmental equity, grant concession etc. can be used or have been used in the socialization of public services.

\section{Conclusions}

As Chinese government start to promote the construction of service-oriented governments these years, the socialization of public service will become a tendency in China. Since the socialized public service system becomes a mainstream all over the world, it would be a good choice for public management reform. In China, the socialist market economy system is improving and the development of economy is becoming better. The responsibility of government will be focus more on the macroeconomic regulation and market management. The government will not need to supply most of the public services and public goods. The market and 
society will take these responsibilities gradually. Although this may take a long time for Chinese government to change the public service system from administration to socialization, this is definitely a better choice for the construction and reform of Chinese government.

\section{References}

[1] He Yunfeng. MengXiangrui, Government's Catalytic Role in NGOs and Socialization of Public Services, Journal of Shanghai Normal University(Philosophy \& Social Sciences Edition), Vol.40 No.4, July 2011

[2] Li Haiyan, Competition, Multicenter Governance and Public Service Reform in China, Henan Social Sciences, Vol.12 No.6, Nov.2004

[3] Staats, "Public Service and the Public Interest," p.601

[4] Sun Xiaoli, Public Service Reform in China: Ideas and Strategic Challenge, Journal of Renmin University of China, No.5 2004

[5] Zhang Yanli, The Challenge and Strategy in the Construction of the Public Service System, Journal of Shandong Administration Institute \&Shandong Economic Management Personnel Institute, No.5, Oct. 2009

[6] ZhengGuangliang, Current Proper Choice on the Methods of Making Public Service Socialized in our Country, Journal of Liaoning Provincial College of Communications, Vol.7 No.2, 2005 